\title{
APPALLING ACTS OF BRUTALITY WITH SEXUAL SLAVE GIRLS: SUBALTERN COGNIZANCE AND SOCIAL CRUSADING IN SOMALY MAM'S AUTOBIOGRAPHICAL RECOUNT
}

\author{
Hassan Bin Zubair ${ }^{1 *}$, Bakhtawar Salim ${ }^{2}$, Saima Larik ${ }^{3}$
}

${ }^{1 *} \mathrm{PhD}$ Scholar (English Literature), Department of English, National University of Modern Languages, Islamabad, Pakistan; ${ }^{2}$ M.Phil English (Literature) Visiting Lecturer in Ghazi University, Dera Ghazi Khan, Pakistan; ${ }^{3} \mathrm{PhD}$ Scholar (English Literature), Lecturer (English), Department of Linguistics \& Social Sciences, Begum Nusrat Bhutto Women University, Sukkur, Pakistan.

Email: ${ }^{1 *}$ hbz77@yahoo.com, ${ }^{2}$ meman275@gmail.com, ${ }^{3}$ saimalarik0@gmail.com Article History: Received on $17^{\text {th }}$ March 2021, Revised on $27^{\text {th }}$ April 2021, Published on $29^{\text {th }}$ April 2021

\section{Abstract}

Purpose of the study: This research explores Somaly Mam's The Road of Lost Innocence through the perspective of gender subaltern in which she calls for collective activism to empower sexual slave girls' position and status in society. She raises her voice against the dominant social force to establish her own space and other sexed women's space in society

Methodology: This research is qualitative in nature. To analyze the selected text, few critics and writers have observed the text from different perspectives. Theories of Spivak, Guha, Suzette R Grillot, Heidi Hoefinger, Nicholas Kristof, Abigali Pesta, and Karen Thornber support this research to find the answers to the research questions.

Main Findings: Mam depicts unspeakable acts of brutality with sexual slave girls in brothels. Through writing, she appeals to all people in the world to take the issue of sexuality and girl trafficking seriously which is horrible these days.

Applications of this study: This paper will emphasize Mam's subaltern consciousness which is ambivalent consciousness. Mam requests for collective activism to eradicate women's exploitation from the world. Her activism looks contributory but paradoxical.

Novelty/Originality of this study: The study is novel in its approach and methods of research in autobiographical literature. Despite being an orphan, domestic and sexual slave girl, Mam succeeds to be an activist and reformist through her struggle. Her activism plays important role in the field of sexual slavery and girl trafficking.

Keywords: Subaltern Consciousness, Activism, Domination, Representative, Patriarchy, Ambivalence, Solidarity.

\section{INTRODUCTION}

The present research attempts to explore the ambivalence of subaltern consciousness in Somaly Mam's The Road of Lost Innocence. Mam focuses on NGO activism instead of political and national activism which is the imperial notion of liberation. Mam's autobiography, on the one hand, goes against domination, subordination, violence, and patriarchal society but on the other hand, Mam accepts the hegemony of NGOs. Subaltern historians believe that subaltern character turns to be a very radical autonomous revolutionary being after getting subaltern consciousness (Yasin et al., 2021) but Mam is not a liberated autonomous rebellious individual rather an agent of an NGO. Mam is a sexual slave girl who turns to be an activist in the field of sexual slavery. She contributes from minimum level to collective conscience for broader solidarity of gender subaltern and somehow empowers sexed women position in society but this is not an appeal for a radical transformation of gender subaltern. For radical transformation, political and national activism is necessary which is not mentioned by Mam. Therefore, this research paper projects the ambivalence of subaltern consciousness in Mam's The Road of Lost Innocence. The autobiography, The Road of Lost Innocence published in 2005 is a story of a sexual slave girl Somaly Mam. It depicts the experience of sexual and domestic slavery of Mam, her struggle to create space in the society, and concerning moreover with the issue of sexual slavery in Cambodia. Mam engages her reader to think seriously about the pathetic condition of sexual slavery which is horrible these days by traffickers. Mam reflects the brutalities of sexual slave girls caused by their parents and relatives for the greed of money. The author is conscious of the position, space, status, and identity of women in society. It is necessary to involve in the mission of anti-trafficking to stop slavery and girls trafficking by all people in the world. The author, therefore, appeals to people to hear the voice of sexual slave girls and protect them from the hellish life of brothels and traffickers.

This research deals with the consciousness of the subaltern character Somaly Mam in the text The Road of Lost Innocence which is in-between consciousness. Mam is an orphan girl from the countryside of Cambodia. She was sold in the brothel by her so-called grandfather when she was sixteen years old. She suffered unspeakable acts of brutality and witnessed horrors in the brothel. When she watched the vicious murder of her friends then she decided to escape from brothels. There are many modes of getting consciousness. In some cases, consciousness comes from revolutionary ideas, political consciousness, and co-incidentally after too much domination and suppression. Mam gets consciousness after too much domination and violence. Subaltern character becomes rebellious and autonomous after having consciousness. But in the text, Mam tries to escape from the brothel with the help of her customer and can escape. She does not go against brothel owners after getting consciousness but flew to France. She has no capacity to revolt at first that's why she 
escapes but after one year, she raises her voice against the dominant force. Subaltern consciousness is a revolutionary consciousness, radical transformative consciousness, political consciousness, and power hegemony consciousness which search the radical transformative way to be out. It is a real reformative consciousness. In the text, Mam is a gender subaltern protagonist but she is not a liberated autonomous subaltern character. She accepts the hegemony of NGOs after being free from brothel and brothel owners. She escapes from the brothel with the help of a foreigner later she marries him and flew to France. She does not come out of the brothel by the revolutionary spirit. But one year later she returns to Cambodia and raises her voice against brothel owners with the help of an NGO which rescues many sexual slave girls. It is not a feature of subaltern character consciousness because subaltern character becomes more autonomous revolutionary being after getting subaltern consciousness. Mam is not an autonomous individual subaltern character but her contribution and activism in the field of sexual slavery cannot be ignored. So her acts look contributory but paradoxical.

Somaly Mam was born in 1970/71 in Cambodia. She studied her school level at a local school. When she was sold in a brothel she was only sixteen years old. She suffered from brutal torture and violence in the brothel that's why she escapes from the brothel with the help of a customer. She flew to France and one year after returning to Cambodia and dedicated her life to saving girls from traffickers and brothel owners. She rescues many girls, provides them shelter and skills to reestablish new life as normal women. Her Anti-trafficking mission gains internal support. NGO and INGO from different western countries help Mam provide funds to her NGO. She wins Glamour Magazine Women of the Year, the Prince of Asturians award, Daily Beast Women in the World for her brave act and mission of anti-trafficking. Many people are interested in her span of life that's why she published Autobiography The Road of Lost Innocence (2005) in which she appeals to the people in the world to involve in the mission to stop girls' slavery and trafficking.

The Road of Lost Innocence tells the story of Mam's brutal experiences and the story of her awakening as an activist and her harrowing and fights against corrupt forces that steal the lives of many innocent girls. It raises issues of sexual slavery and girls trafficking in Cambodia. Mam demonstrates that domestic and sexual slavery is taken to be normal in Cambodia which is a curse for innocent girls. It shows the degradation of human civilization. Mam raises their voice to empower sexed women's position in society. She goes against brothel owners to save girls from a hellish life. She appeals for collective activism to eradicate girl trafficking and the exploitation of women from the world because domination of women is pervasive throughout the world. Her calls for collective solidarity of women look good and contributory but her means of activism is NGO activism which is not able to eradicate sexual slavery without political and national activism. The autobiography tries to give justice to women in society who are always ignored in a patriarchal society. The male-dominated society pushes the existence of females in critical condition. Male regard themselves as superior to females. Eventually, they misuse and dominate females to fulfil their desire. The patriarchal societies establish rules and regulations without proper attention and thinking about female and female rights. Mam brings the story of other sexual slave girls who are sold by their parents for money. Male invest money in girls to fulfil their sexual desire and they have no sympathy towards women. Mam is not being valorised from the mass national oppressed subaltern group of people. She gets an award from the international elite circle. She is objectified by Glamour Newspaper. So, patriarchal society's rules and regulations turn to be destructive for females. A large part of the globe is involving in exchanging the culture for far distance (Zubair, 2021, p. 2845).

Mam is a highly submissive gender subaltern character which is not possible to all the subaltern women in general. She becomes a role model of gender subaltern, not all subaltern women can achieve the same status and position as Mam. Her struggles and practice of empowering sexual slave girls' positions somehow help to empower the position of subaltern women in her society. Mam tries to give a lesson to sexed women to raise their voice for their rights and identity in society. To establish existence in society, it becomes a duty to be conscious and care about the position and rights. Mam gives hope to those sexual slave girls who are in a hopeless situation. So, Mam's narrative inspires many sexual slave girls to go against the dominant social power structure for their rights and identity. Grillot, 2013, p.6) claims autobiography as a source of inspiration to those sexed women what he tittles, "Human Trafficking Board of Regent of the University Oklahoma". In the journal, he asserts:

"This is a first-hand account of exploitation survival and courage offers an incredible inside view of the sex trade. As if escaping the life of forced prostitution is not difficult enough, Mam shows us how triumph over tragedy leads to a determination to help others do the same. Unable to leave behind those who like her, were imprisoned in the brutal world of sex work. Mam gives hope that bravery can defeat brothels" (Grillot 2013, p.6).

$\mathrm{He}$ argues that Mam's determination is the main reason behind the triumph over brothel owners. Her strong determination to support others is a risky task. The bravery and courage to face any problems lead towards triumph. That's why Grillot focuses on Mam's bravery which is the main cause of demolishing brothels and brothel owners' supremacy and domination.

Similarly, Nicholas Kristof in the article, "Fighting Back: One Brothel Raid at a Time", asserts Mam as an antitrafficking activist from a slave girl. He argues, "Somaly dedicates her life to battling forced prostitution, for her herself was sold as a child to a Cambodian brothel. After enduring torture and rapes, Somaly escaped and reinvented herself as an Anti-trafficking activist. She convinced Cambodia's Anti-trafficking police to mount raid" (Kristof 2011, p.3). He 
demonstrates Mam as an anti-trafficking activist first time who keeps the capacity to register cases against the owners of brothels. She is a fearless woman who does not stop mission to raid brothels also after brothels owners fight back ferociously against her. Kristof praises Mam for her dedication to sexual slave girls. Mam dedicates her life to stopping forced prostitution. Abigali Pesta criticizes those people who are against the autobiography The Road of Lost Innocence because Mam shares a personal experience about sexual slavery in front of the world. In the article, "Somaly Mam's story: I Did not Lie", Pesta mentions Mam's view when people of Cambodia and other countries also criticize her for unfolding personal experience. Mam gives a reply to those people as, "If girls want to talk about their story, they can. I do not tell anyone they have to do it. I have told my own story. Mine is enough. Why do we need to be silent in the brothel? Why be silent now? Enough" (Pesta, 2014, p.3). It shows that males are not happy with Mam's story because she unfolds her brutal experience of the brothels and sexual issues openly which is not accepted by male supremacy. That's why she claims that it is enough now, we should not remain silent but raise voices against domination and subordination. She questioned why we should be silent forever. Mam shares her story to show the reality of sexual slave girls in Cambodia in front of the world. Mam shows her anger towards those people who want sexed women who need to be silent.

Karan Thornber praises Mam for her effort to combat girl traffickers. He states, "The Cambodian human right advocates Somaly Mam's French-language memoir on her experience with and struggle against sex slavery, almost all of the women who seek help from AFESIP, the NGO Mam founded to combat human trafficking and sexual exploitation in Southwest Asia" (Singer, 1998). AFESIP's efforts in ending sex slavery include monitoring and preventing the trafficking of girls from Cambodia and Thailand to other countries. Similarly, Rocap asserts that "Miraculously, Mam survived the atrocities that she was subjected to and is now an activist. She founded and runs a non-governmental organization which translates from acting for women in distressing situations" (Rocap 2011, p.72). AFESIP was founded in 1996 in Cambodia and spread to Thailand and Laos which have similar sex slave industries like Cambodia. It provides shelters, takes care, providing health treatment and occupational skills to those rescued girls. Its aim is not only to rescue them but also to reintegrate them into their society.

Heidi Hoefinger takes The Road of Lost Innocence as a source of inspiration for sexual slave girls which provides hope and strength to go against the dominant force. He analyses Mam story as, "Mam's story has both inspired and shaken the global anti-trafficking movement ... Autobiography virtually projected Mam into the world as the beautifully damaged, global anti-trafficking poster child" (Hoefinger, 2011, p.2). He praises Mam for her courageous combat against brothel owners and traffickers by transforming herself into an activist from a slave child. Mam learns to resist extreme mental and physical torture. She gives hope to subaltern women how to come up from hopeless situations. She supports Antitrafficking movements. Mam turns to be somebody from nobody instead of being an orphan and slave.

\section{RESEARCH OBJECTIVES}

- To highlight the issues of girl trafficking.

- To present the concerns of sexual slavery.

- To analyze the subjects of unspeakable acts of brutality.

\section{RESEARCH QUESTIONS}

1. How has Somaly Mam presented the acts of brutality with sexual slave girls in brothels in her novel The Road of Lost Innocence?

2. How Somaly Mam has illustrated the role of activism to counter sexual slavery and girl trafficking in her novel The Road of Lost Innocence?

\section{THEORETICAL FRAMEWORK AND RESEARCH METHODOLOGY}

This research is qualitative in nature. To analyze the selected text, few critics and writers have observed the text from different perspectives. The Road of Lost Innocence raises the issue of sexual slavery and girls trafficking. Almost all critics focus on the issue of girl trafficking and Mam's tragic life was it raised many issues too. Somaly Mam is an example of a gender subaltern woman who became an activist from a sex slave girl. Mam's story does not only raise the issue of girl trafficking, but it reveals the reality of sexual slave girls and tries to empower sexed women's position in society. It requests all people in the world to take the issue of slavery seriously. Therefore, this research analyses The Road of Lost Innocence from the perspective of gender subaltern. In this regard, this paper explores Mam's ambivalent subaltern consciousness. The term subaltern refers to those groups of people who are at the margin in society and have no political agency. Subaltern is a term coined by Italian Marxist Antonio Gramsci in his notable work Prison Notebooks. Gramsci used the word subaltern to refer to those groups of people who are, "Subject to the hegemony of ruling class" (Gramsci, 1971, p.14). It means subaltern people are suppressed by an elite hegemonic power structure. Gramsci defines the term subaltern as, "The groups that are excluded from a society's established structures for political representation and therefore denied how people have a voice in their own society" (Gramsci 1971, p.43). He is interested in the historiography of the subaltern classes. He claims that the history of subaltern people is a complex as the history of the ruling class because subaltern history is fragmented, episodic, and subjective. Gramsci's main aim of term subaltern 
is to liberalize the suppressed voices by challenging authoritative voices. Ranjit Guha uses the term subaltern to refer to the peoples who are "socially, politically and geographically outside of the hegemonic power structure of the colony and of the colonial homeland" (Guha, 1989, p.87).

In the 1980s the scope of inquiry of subaltern studies was applied as an "invention in south Asian historiography" (Spivak 1986, p.21). The subaltern study focuses on the perspective of the colonized and challenges the colonizers' perspective upon South Asian history. Guha explains subaltern studies groups aim as, "The aim of subaltern studies is to promote a systematic and informed discussion of subaltern themes in the field of South Asian studies" (Guha, 1989. p.48) and defines the term subaltern as "a name for the general attribute of subordinate, whether this is expressed in terms of class, caste, age, gender, and office or in any way" (Guha, 1989, p.27). Venna Das in her essay, "Subaltern as perspective" asserts that "The question of gender subaltern construction of the subaltern has been largely absent from the purview of the studies mentioned here an exception is Guha's paper on Chandra's death" (Das, 1989, p.32). Spivak revolutionized the existing course of the subaltern in her philosophical essays entitled, "Can the Subaltern Speak?" and "Subaltern Studies: Deconstructing Historiography". In "Can the Subaltern Speak?" she focuses on themes including representation, insurgency, and passiveness of gender subaltern and critique of attempt to speak for the most marginalized. She defines subaltern as, "The oppressed subjects or more generally those of inferior rank" (Spivak, 1986, p.283) and subaltern position as, "The subaltern is not privileged and does not speak vocabulary that will get a hearing in institutional location of power" (Spivak, 1986, p.12). She advocates for gender issues in subaltern studies. She claims that "The subaltern as female is even more deeply in shadow" (Spivak, 1986, p.287). It shows that female is in double suppression and domination. Kamala Visweswaran also criticizes male subaltern theorists to put gender subalterns under topics of caste and class. She asserts, "Either gender is subsumed under the categories of caste and class or gender as seen to make a social group apart from the other subaltern" (Visweswaran, 1996, p.88). She focuses that gender subaltern should be considered the separate issue in subaltern studies not about caste and class.

Subaltern consciousness had always been a critical feature of subalternity. Ajit k Chaudhary reiterated that "The focus of subaltern studies is on the consciousness of subaltern classes, especially peasants" (Chaudhary, 1995, p.108). Different subaltern theorists define subaltern consciousness differently. Spivak defines, "Subaltern consciousness is subject to the elite that is never fully recoverable that is always from its recovered signifies indeed that is effaced even as it disclosed that it is irreducibly discursive. .." (Spivak, 1986, p.339). Spivak's more focus is on the gender subaltern consciousness. The gender subaltern is more dominated and suppressed than other subaltern groups of people. Spivak focuses on, "... consciousness here is not consciousness in general but a historicized political species subaltern consciousness" (Spivak, 1986, p.338). Chatterjee believed that the politics of the subaltern constituted an autonomous domain for it neither originated from elite politics nor did its existence depend on the latter. He claims that "It neither originated from elite politics nor did its existence depend on the latter" (Chattergee, 1989, p.11). In, The Road of Lost Innocence, there is a local, national and international hegemony. She is a victim of local people and governmental officers. NGO is one of the hegemonic forces in the text. So, the gender subaltern perspective is applicable in the autobiography The Road of Lost Innocence.

\section{TEXTUAL ANALYSIS}

The Road of Lost Innocence is about the issue of sex slavery and the domination and subordination of women in society. Various writers have been writing many texts regarding the issue of female domination. Mam is one of them who tries to raise women's issues in front of people in the world. Mam in the text reveals the crucial reality of sexual slave girls and her efforts to save girls from brothel owners and traffickers. She appeals for collective activism to stop girl trafficking. She advocates on behalf of sexual slave girls who are under the suppression of brothel owners. In The Road of Lost Innocence, Mam presents the brutality of a patriarchal society where women have no value and identity. The female is objectified to fulfil the sexual desire of males. So, the writer challenges dominant social norms and values regarding women. Mam focuses on the gendered subaltern. She tries to give justice to those women who are dominated and suppressed by patriarchal rules and regulations. Mam is a gender subaltern protagonist. She is a subaltern character in terms of gender, race, color, education, ethnicity, geography, occupation, and class. Gramsci defines subaltern characters as, "subordination in terms of class, caste, gender, race, language and culture and was used to signify the centrality of the dominant/ dominated relationships in history" (Gramsci, 2003, p.5). Mam is a sexual slave girl, widow, domestic slave and comes from the countryside of Cambodia. She is sold in a brothel by her so-called grandfather after the death of her first husband. She suffers from unspeakable acts of domination and subordination during the period of sexual and domestic slavery. She is insulted due to her profession and color of skin. The people insult her like a nonhuman being by calling her, "A dirty dark-skinned girl with no more brains than a lump of wood. They push me, yelled at me, insulted me" (Mam, 2007, p.11). It shows that Mam is compared with wood because wood is a passive thing that does not have a life and brain. For males, Mam has no existence in the world unless object. Mam is a victim of the male gaze and patriarchy. Males compel her to be a sex worker by sold in the brothel but they call her whore. A customer who has a sexual relationship with Mam calls her, "He called me a whore- don't try to give me any lesson, whore" (Mam, 2007, p. 96). He does not feel guilty by calling her whore but he considered himself pure and considered Mam as filthy. Mam lives in a traumatic situation due to the selfish nature of a male-dominated society. 
Mam is a victim of patriarchal society. She is a victim of a male-dominated society which compels her to be a domestic and sexual slave where she suffers from mental and physical violence. Grandfather keeps her at his home for his service. Mam mentions, "I would become his indentured servant, domestic servant, and unpaid servant" (Mam, 2007, p. 13). Her grandfather and first husband sexually abuse her when she was thirteen years old. In a patriarchal society, males can do whatever they want to do with a female without her permission and it should not be considered a crime. Ranjit Guha argues, "Dande is depicted as male there could be nothing wrong about exploiting women by forced either for labor or men's sexual gratification" (Guha, 1996, p.239). It shows that female is nothing other than a sexual puppet for a male which provides pleasure but does not have any value in their life. Mam endures physical torture when she refuses to have sex with her grandfather, "He would make me kneel and beat with a long hard bamboo that cut into my flesh and made me bleed with every below" (Mam, 2007, p. 13). Mam suffers from mental and physical violence. Domestic violence is still privileged in society but nobody could raise a voice against that crucial system of torturing. So, Mam is a victim of domestic violence and suppression.

Through self-representation, she tries to give space to subaltern women. She is conscious of her space, position, and identity in her society. Subaltern consciousness means subaltern people know or are conscious about their space, right, and position in society and go against elite people for the sake of their welfare and existence. This research mainly focuses on gender subaltern consciousness, not consciousness in general. Spivak claims, "Consciousness here is not consciousness in general but a historicized political species, subaltern consciousness" (Spivak, 1986, p.338). She focuses on the gender subaltern consciousness because gender subaltern is more deeply in the shadow of the dominant force. Gender subaltern consciousness is about the awareness and consciousness of women about their position, identity, and space in society. When they feel that they are dominated they go against dominant power. Mam creates her own space in her society through her struggle. Mam tries to become somebody from nobody and can establish her position in society from where she is discarded and neglected. She involves in the mission to save girls from traffickers which makes her an international figure from the sexed girl. Her mission helps women voice their voices. That's why subaltern consciousness is necessary to break the silence of subaltern groups of people.

After subaltern consciousness, the subaltern character turns to be an independent autonomous individual. Gautam Bhadra in his essay, "The Mentality of Subalternity" depicts subaltern groups of people's mentality of resistance as:

"It is well known that defiance is not only characteristic of the subaltern classes. Submissiveness to authority in one context is as fragment as defiance in the other. It is two elements that together constitute the subaltern mentality. It is an account of this combination that the poor had the oppressed have time and again in different histories voluntary sacrifices in favor of the rich and dominant at last as often they have rebelled against the latter" (Bhadra, 1989, p.54).

From this quotation, it is clear that subaltern people rebelled against domination and subordination when they are oppressed again and again. Subaltern people do not only resist silently but they are violent, "when they rebel, they are in a state of anxious defense" (Gramsci, 1971, p.10). When dominant forces give too much pain and torture, dominated subaltern groups of people start to resist violently. Similarly in the text, Mam resists the customer's misbehavior. She is ready to kill a crucial customer when he misbehaves with her brutally. She mentions, "I fired the gun. I was just so angry. The bullet hit his leg" (Mam, 2007, p. 45). So, the environment and situation of what is happening around subaltern people are intersected with the act of resistance.

Mam's perspectives towards the Cambodian government are negative. She shows Cambodian government and its officers are corrupt and immoral. She generalizes all officers in the misdeed of some officers. Mam puts a request to a governmental institution to rescue girls from traffickers and brothel owners but the Cambodian government does not give proper attention to her request. The government officers take bribes from the dominant force and ignore marginal people's issues. Mam argues, "With money. you can a buy a judge, policeman- whatever you want corruption is like a gangrene at the heart of the Cambodian people and legal system" (Mam, 2007, p. 89). According to her, money is everything for responsible officers of government. The police officers are running after money instead of helping exploited people. It is not good to generalize all officers to the misdeeds of some particular officers. Mam cannot able to do anything if the police of Cambodia do not give support and help her in a raid on brothels. She highlights her deeds and backgrounding police contribution in a raid on the brothels and rescue girls from traffickers. She claims, "We made so much fuss about it that the police agreed to raid the brothel. I think they do not want to lose face ... too many of them were involved in the sex trade themselves. They worked as guards or went to the brothels as clients. Many of them were even investors" (Mam, 2007, p. 136). She shows that government is almost corrupt and involve in immoral activities. She does not give any value to those innocent police officers who help in her mission. The police officers help Mam with her every step. She mentions, "That first raid was a farce. There were half a dozen policemen with me" (Mam, 2007, p.136). It shows that there is involvement and contribution of police in saving sexed women from brothels. She mentions their involvement in her mission but backgrounding their good deeds and highlights bad deeds, "It is worse outside. At least here, we were protected from the police" (Mam, 2007, p. 58). She keeps her view negative due to some of the police offices. She only highlights the corrupted things of police and ignored the good things of police. That's why it is itself contradictory. 
The role player is an exploiter or a savior of Mam. The role player is a customer of Mam. Pierre a customer of Mam later helps her to escape from the brothel and supports her in every step of her acts. He is a foreigner who comes from France to Cambodia as an NGO worker. He used to visit a brothel to have sex with Mam. He is interested in Mam and has a Feeling of love towards Mam. Mam says, "But one time a man seemed to be interested in me. He came several times. We almost became friends. He told me that he love me and wanted to marry me. This was after six months we moved to Aunt Peuve's . . . there was a way out" (Mam, 2007, p. 55). Pierre is a medium for Mam to escape from the brothel. He helps Mam to escape and marries her. He supports every step of her life and problem. He helps her to run NGO and Supports her act the anti-trafficking mission. So, it is paradoxical that Pierre is an exploiter or a savior of Mam. There is a double role of same customers. The same customer becomes a savior and an exploiter in the case of Mam. Pierre is also suffered by Mam. When she gains name and fame she gives divorce to Pierre. Other customers also help Mam. Dietrich is a customer of Mam who cares for her and provides money for her because he does not want to see Mam in the brothel again. He wants to take Mam to Switzerland but Mam refuses. So, it is difficult to separate customers as exploiters or saviors of Mam.

\section{FINDINGS AND DISCUSSION}

Mam speaks against dominant social power structures which are made by the male to dominate women. She challenges male-orientated rules which are responsible to make women passive, dependent, and helpless. She appeals for collective activism to dismantle defiled force's supremacy. Her collectivism is an NGO activism that's why she is not able to eradicate women's domination and subordination. It only acknowledges women that are suppressed and repressed. National and political activism is necessary to justify women's equality and identity in society. But she accepts NGO activism which is questionable. NGO is itself an imperialist mission of liberation where we found hidden imperial faces. She chooses hegemony of the NGO after being free from a brothel. She frees from one hegemonic power structure and enters another hegemonic force. She has a lot of contributions in the field of sexual slavery. She runs NGO to eradicate girl trafficking. "We had decided to call it something mild- we know we had to avoid attracting too much attention to the girls who would be living there. We settled on AFESIP-'Acting For Women in Distressing Situation" (Mam, 2007, p. 155). She opens an NGO and appeals to NGOs and INGO from western countries for funds instead to take help from the government of Cambodia. Mam mentions, "We took our project to the European Union Office ... UN agency promised us funds and funds from UNICEF" (Mam, 2007, p. 156). It shows that she follows the path of the imperial mission of elite people. From this, it is clear that she is not an autonomous subaltern character instead of an agent of NGO. She goes against patriarchal rules and regulations but at the same time, she accepts NGO's domination in her life. So, it is questionable itself because she is not free from domination only dominant agency is different.

Mam is a highly subversive gender subaltern protagonist. She has been transformed slave to an activist. It is not possible to all subaltern people in general to achieve success like Mam. She is a role model of gender subaltern. She speaks against the dominant social force to create her space in society. Her struggle and fight against brothel owners show that subaltern women also raise voices against suppression but their voices are ignored in a patriarchal society. Mcheod writes about the Spivak as:

"It does not speak but rather that others did not know how to listen how to enter into a transaction between speaker and listener. The subaltern cannot speak because their words cannot be properly interpreted. Hence, the silence of the female as a result of the failure of interpretation and not a failure of articulation (Skartun, 1995).

It shows that subaltern women can speak but their voices do not give proper meaning, interpretation, and value to dominant people. That's why it is not a failure of articulation but it is a failure of interpretation. Elite peoples do not hear marginal peoples' voices at first and if they heard, they misinterpret, misjudge marginal people's voices, and do not care about dominated people's feelings and emotions which are connected with voices.

The ideological construction of gender is one cause of women's downfall. Patriarchal society constructs the role of gender in society. Gender is not an inborn trait of a human being rather it is constructed by society. Mam tries to establish women's position in her society by going beyond the ideological concept of gender. She deconstructs stereotypical images of women as passive, emotional, dependent, savage, and so on. She challenges rules made by the male to suppress women in their every step of life. Spivak herself recognizes that the ideological Concept of the female is fraught with epistemic violence by claiming that, "The ideological construction of gender keeps male dominant" (Spivak, 1986, p.18). Male shows themselves superior over female. The patriarchal society looks female from the perspective of sexuality. Females are victims of the male gaze by, "This, however, is an explicit masculinist gesture: turning women into rivals by making them objects of gaze" (Spivak, 1986, p.134). The male looks female only from the perspective of sexual gaze no more than that. Males have a strong desire to have sex with a female but do not have any kind of sympathy and emotion towards females. The ideological construction of gender makes females weak and passive. Mam is not being valorized from the whole mass national oppressed subaltern groups of people rather she is valorized from the international elite circle. Mam is getting an award from glamour newspaper. She wins a Glamour Magazine Woman of the year award in 2006. This award is given to her for their contribution to girl trafficking. She says, "It was a wonderful night, full of emotion, support, and hope. I had not realized that our cause would touch so many people" (Mam, 2007, p. 120). She feels grateful for those people who support her. Her work is awarded by the elite 
magazine but not awarded by mass groups of people. She wins other awards from foreign countries and INGO for her work but she is not awarded by local people. It is ambiguous that she is rewarded by the elite, not by those people for whom she works and speaks.

Mam gives voice to herself through literary representation. She published the autobiography The Road of Lost Innocence to give voice to herself. She demonstrates all her personal experiences in the text. Mam shares her experience about sexual and domestic slavery in front of people which helps to hear her voice. It is one way of voicing voiceless people. Female subaltern voice is disappearing because, "Gender subaltern disappear because we never hear her speak about herself" (Gandi, 1998, p.29). It means the female cannot speak for herself that's why she is always dominated and ignored by society. But Mam chooses the way literary representation to give voice to gender subaltern. She depicts all the brutal things that happened with her during the period of domestic and sexual slavery in front of people of the world. It requests people in the world to hear her voice. She has a direct experience of all these things that's why people believe in her tragic story. Julie Stephen argues, "A distinguishing feature of contemporary feminist discourse is that purports to speak about real women. It claims to record the direct experience of women" (Stephen, 1989, p.92). It shows that the authenticity of real experiences which have more possibility of accepting truthfulness of the story by readers.

The Road of Lost Innocence is written from the perspective of a sexual slave girl. It is a story of a slave girl who is forgotten and discarded from her society. Sexuality is a marginal issue and it is valorized by Mam. Mam says, "When I was sold to a brothel as a prostitute, I was about sixteen years old. There are virgins for sale in every large town: to be sure of their virginity, the girls are something as young as five or six" (Mam, 2007, p. 2). It raises the issue of girls' trafficking and sexual slavery which is ignored by elite people. Elite people do not talk about the issue of sexuality. It is a marginal issue. So, Mam highlights non-elitist people's issues to centralize. Mam's The Road of Lost Innocence is one of the representative stories of gender subaltern. It represents the voices of all sexed women. Mam becomes the voice of all sexual slave women. She argues why she writes this book as, "I am writing about it to make visible the lives of so many thousands of other women. They have no choice; so, let this one life stand for their story" (Mam, 2007, p. 207). She represents all girls who live hellish life in brothels and who cannot speak due to fear of their master. Mam's personal story makes visible the lives of many thousands of sexual slave girls. Mam's story is the only representative story of all sexual slave women. Mam believes that one day people in the world could hear the voice of sexed women. So, it is necessary to continue writing about a personal experience that challenges males' representation of women in their writing. Confessional writing is a weapon of women to destroy the male point of view about females. Rosemary argues that "re-writing will inevitably destroy the images of women as passive beneficiaries of the struggle for equal rights waged by other on their behalf . . I felt that women's voice once it is heard, will activate and make audible the other small voices as well" (Sayigh, 1999, pp.11-12). It focuses on the importance of writing to make the voice audible. It inspires women to write for their equality and identity which challenges the male point of view about women in writing. That's why the day will come when women's voices could be heard and be interpreted throughout the world. Mam's narrative inspires subaltern women to fight back against domination and subordination. It inspires many sex slave girls to come up with various forms of internal and external domination and subordination. It is essential to create one's history and space in society oneself. Mam is a brave woman who endures all difficulties easily in her life. She does not care about what others think about her but she has a strong desire to do something for sexed women. She mentions:

"I thought I would show those villages that even if you have been a prostitute, even if your skin is dark, you can still be a good person. You can be clever and you can succeed. After the way they had treated me, I had made a good life for myself. I was helping others and they could do that too." (Mam, 2007, p. 162)

It inspires sexed women to live life like normal human beings. Mam's story motivates women to do something better in life in front of those people who ignored them. Mam is neglected, ignored, and isolated from society but her strong determination creates her space in society which makes her an activist. She helps sexual slave girls to re-establish new life. She provides hope to that female who is in a hopeless situation. She is a self-made person.

Mam focuses on NGO activism throughout the text but at last, she appeals to all governments of the world to get involved in the anti-trafficking mission. She only criticizes the government of Cambodia and praises foreign agencies for their support and help. But at last, she writes that The Road of Lost Innocence is a call for a collective mission to stop the sexual exploitation of women. She says that "I would like this book to serve as a call to the governments of the world to get involved in the battle against the sexual exploitation of women and children. Victims are victims in every country" (Mam, 2007, p. 207). She appeals to governments throughout the world to help in the battle against the sexual exploitation of women. The exploitation and domination of women are pervasive everywhere in the world. So, a universal or collective mission is necessary to make society free from the sexual exploitation of women. It shows that at last, she knows that national and political activism is necessary to address the issue.

The Road of Lost Innocence depicts the suppression, repression, violence, domination, and subordination of the gender subaltern character Somaly Mam. Mam is a minor modality of gender subaltern who is transformed from a slave to an activist through personal struggle. She goes against the dominant power structure to give justice to herself and those sexual slave girls who are the victims of patriarchy. She tries to empower women's position in society and bring the issue of sexuality into the mainstream. Mam's personal story inspires many other slave girls to raise voices against the corrupted social power. Mam's transformation from a slave to an activist through her brave act provides hope to other 
sexed women. It is a transformation of a subaltern woman despite being an orphan, domestic and sexual slave girl. She raids on the brothels with the help of the anti-trafficking policy of Cambodia. She does not only rescue girls from brothels but also provides shelters and skills to restart new lifelike as usual. She runs NGO which helps sexed women and raises a voice against girls trafficking.

Mam has a brutal experience of sexual slavery in a brothel which forces her to escape and raise her voice against the brothel owner. Mam somehow achieves success in rescuing girls from brothels but not all sexual slave girls are free from sexual exploitation. So, she appeals for activism but her activism is itself problematic. She chooses NGO activism to give justice to sexed women which is the imperialist notion of liberation. Without national and political activism it is not possible to give justice to sexual slave girls. It is necessary to address women's issues from a political dimension only after equality between men and women is possible. She has given the focus on NGO activism instead of political and national activism. She praises INGO's from western countries and foreign people and never criticizes them. She does not praise local people in Cambodia who give help in her mission. Mam is not an independent autonomous subaltern character. She accepts NGO hegemony after being free from the hegemony of brothel owners. After getting subaltern consciousness, the subaltern character becomes more autonomous and never accepts any kind of domination. But Mam accepts NGO hegemony. Mam Claims that those governmental officers are too corrupted that she has no other option instead of running an NGO. She plays a role from a minimum level and gets success in her mission. She does not focus on political, social, and national activism rather she focuses on NGO activism which is no ultimate way of liberation. Her activism somehow helps to empower women and acknowledged women about their oppression. But it is not an ultimate way to empower women's position in society. Without political activism, it is impossible to provide equality to women.

\section{CONCLUSION}

Mam plays important role in the anti-trafficking mission. She brings the brutal reality of sexual slave girls in front of people of the world and raises her voice against the dominant social power structure. Her mission rescues many slave girls from the hellish life of brothels and somehow stops girls trafficking. She requests people in the world to hear the voice of sexual slave girls. She appeals to all people in the world to involve in the mission to eradicate women's exploitation from the world because it is pervasive throughout the world. She did what is supposed to be done by intellectuals. She plays an important role from the minimum level to give justice to sexual slave girls. She can somehow empower the status of sexual slave girls in her society. But it is not an appeal for radical transformation. So, Mam is not great instead of her great work and she is not popular instead of her popularity.

\section{LIMITATION AND STUDY FORWARD}

The study reveals some of the autobiographical aspects of the slave girls written by Mam. More research can be extended to the same genre such as short stories written by Kamala Das and literature written about the kept women and slave women in the South Asian contexts.

\section{AUTHORS CONTRIBUTION}

Hassan Bin Zubair conceived the main idea of the research. He designed the research methodology, worked on the theoretical framework and conducted a major part of data analysis. Bakhtawar Salim worked on literature review and data analysis. Saima Larik worked on data analysis and worked on the overall formatting and corrections of the document.

\section{REFERENCES}

1. Bhadra, G. (1989). The Mentality of Subalternity. Subaltern Studies VI. Oxford University Press.

2. Chattergee, P. (1989). Caste and Subaltern Consciousness. Subaltern Studies VI. Oxford University Press.

3. Chaudhary, A. K. (1995). In search of a Subaltern Lenin. Subaltern Studies V. Oxford University Press.

4. Das, V. (1989). Subaltern as Perspective. Subaltern Studies VI. Oxford University Press.

5. Gandi, L. (1998). After Colonialism. Post-Colonial Theory. Oxford University Press.

6. Grillot, S. R. (2013). Human Trafficking. Board of Regent of the University Oklahoma, 87(4), 6. https://doi.org/10.1353/wlt.2013.0090

7. Grmasci, A. (1971). The Prison Notebooks: Selections. Trans. And Eds. Quentin Horace and Geoffery Nowell Smith. International Publisher.

8. Guha, R. (1989). Dominance without Hegemony and It's Historiography. Subaltern Studies VI. Oxford University Press.

9. Hoefinger, H. (2011). Neoliberal Sexual Humanitarianism and Storytelling: The Case of Somaly Mam. Routledge.

10. Kristof, N. (2011). Fighting back: One Brothel Raid at a Time.”The New York Times.

11. Mam, S. (2007). The Road of Lost Innocence. Virago Press.

12. Mcleod, J. (2000). Beginning Post-Colonialism. Manchester University Press.

13. Pesta, A. (2014). Somaly Mam's Story: I did not Lie. Newsweek.

14. Rocap, A. (2011). The Road of Lost Innocence- A personal account of the atrocities of Cambodia's sex slave industry." Children Legal Rights, 70-75. 
15. Sayigh, R. (1999). Gendering the Nationalist Subject: Palestinian Camp Women's Life Story. Subaltern Studies IX. Oxford University Press.

16. Singer, A. (1998). Can the Subaltern Speak? Marxism and Interpretation of Culture. Oxford University Press.

17. Skartun, G. (1995). A Literary Representation of the Subaltern: Mahasweta Devi's Standayini. Subaltern Studies $V$. Oxford University Press.

18. Spivak, G. C. (1986). Subaltern Studies: Deconstructing Historiography. Subaltern Studies IV. Oxford University Press.

19. Stephens, J. (1989). Feminist Fictions: A Critique of the Category 'Non-Western Woman' in Feminist writings on India. Subaltern Studies VI. Oxford University Press.

20. Thornber, K. (2013). Global Health and World Literature: Translating silences in Cambodian Writing on Sex Slavery. John Hopkins University Press, 31(2), 235-255. https://doi.org/10.1353/lm.2013.0018

21. Visweswaran, K. (1996). Small Speeches, Subaltern Gender: Nationalist Ideology and It's Historiography. Subaltern Studies IX. Oxford University Press.

22. Yasin, G., Waqar, S., Javed, N., \& Naeem, A. (2021). Endurance of the Subaltern: A Study Of A Thousand Splendid Suns By Khalid Hosseini. Humanities \& Social Sciences Reviews, 9(3), 745-753. https://doi.org/10. $18510 /$ hssr.2021.9373

23. Zubair, H. B. (2021). The World is Divided into Center-Periphery Structures: Mohsin Hamid's Exit West Presents the Fiasco of Western Grand Narrative of Globalization. Psychology and Education, 58(5), 2842-2849. 